UDC 327:339.9(510:73)

\title{
UNDERSTANDING THE "GREAT TRANSFORMATIONS ONCE IN A CENTURY”
}

\author{
Zhang Yuyan \\ $\mathrm{PhD}$ in Economics, Senior Fellow \\ Institute of World Economy and Politics, \\ Chinese Academy of Social Sciences \\ $15^{\text {th }}$ Floor of CASS Building, Chinese Academy of Social Sciences \\ No5, Jianguomen Nei Avenue, \\ Dongcheng District, Beijing, PRC \\ yyzhang@cass.org.cn
}

Now the world is experiencing unprecedented changes over the centuries, which will have a more significant impact on the future of humanity than all the transformations of the twentieth century. This period is the best in the development of China in modern history. The article is relevant, and it analyses how and why the world is changing, in which direction. First of all, we are talking about fundamental changes in the balance of power between the leading countries, namely, in relations between China and the United States. Besides, technological change is the most critical change in the world, which causes a chain reaction of massive and sometimes unpredictable changes in production, distribution, exchange, and employment in each sector. As a result, we have another factor of change the spread of the Internet, which led to an information explosion, a drop in the communications cost. The article also discusses demographic changes that cause new problems on the path to economic, social, political stability, and growth.

The change in the US position due to de-dollarisation has also attracted attention. The US gains many benefits from the status of the dollar as a reserve currency; however, the diversity in the international system, in particular digital currencies, is increasing. As a result, the dependence of other countries on the dollar is decreasing. Following the weakening of the state that built the globalization process and another country's strengthening - China, changes are taking place in the international system, which is described in detail in this article. America and China did not solve the cold war but fell into the Thucydides trap. Therefore, the world has already been experiencing influence.

All changes have their constants, and in this case, we firmly remain in the nuclear era, and the interdependence between nations now is at a high historical level. After a hundred years looking back at changes over this period, historians probably will be able to see this moment as a stage in the rise of the East, especially China.

Keywords: China, USA, transformations in the XX century, technological progress, historical changes, information explosion, the process of globalization

World history is a constant flow of change. In the last century, this planet saw so many dramatic events: two world wars, followed by a cold war, and the clash of civilizations between Islam and Christianity; and a kaleidoscope of amazing technological progress. But deeper changes are happening today. As Chinese President Xi Jinping said, "This is China's best period of development in modern history. The

(C) 2020 Zhang Yuyan; Published by the A. Yu. Krymskyi Institute of Oriental Studies, NAS of Ukraine and the Ukrainian Association of Sinologists on behalf of The Chinese Studies. This is an Open Access article distributed under the terms of the Creative Commons Attribution License (https://creativecommons.org/licenses/by-nc-nd/4.0/). 
world is undergoing the most profound and unprecedented changes in a century. The two tendencies have become increasingly intertwined and contentious"1. In other words, the secular changes happening right now will have a greater impact on the future of humanity than all of the transformations of the twentieth century. It was President $\mathrm{Xi}$ who recognized the importance of this critical moment in world history, and his analysis in a speech a little more than a year ago sparked vigorous discussion among China's scholars and researchers. This article has catalogued eight dimensions in which we can identify the depth of these profound changes.

\section{Balance of power: Fundamental shifts}

The most important variable in these secular changes is the balance of power among the world's great powers. The balance of power has been shifting for the past 20 to 30 years, and the creeping changes are now adding up to a qualitative shift in global power. There are many indicators that serve as a proxy for a nation's strength or power; the most broadly applicable remains the size of a country's economy. By this measure, the pace of China's development over the past 40 years has been dramatic.

In 1978, China's GDP per capita was just US\$200; in 2018 it was nearly US $\$ 10,000$. Particularly in the last decade or so, the speed of China's economic growth has exceeded even our own expectations. At market exchange rates, China's GDP was still less than half of Japan's in 2005. By 2010, China's GDP had overtaken Japan, and in 2015, it was twice the size of Japan's. At our current rate of growth, our economy may well be three times the size of Japan's in 2020.

40 years ago, China's GDP was about 2/30 of America's. By 2018, it was 2/3. China is fast closing in on economic size with the world hegemon, the US; and these two countries are pulling steadily further ahead of all other countries in the world. This is the key frame through which we should understand the upcoming fundamental shifts in China-US relations ${ }^{2}$.

Some Chinese commentators see the $2 / 3$ ratio as a crucial marker that heralds a turn for the worse in the relationship between the world's two largest economies. China is not the first country to approach $2 / 3$ of the US's GDP in the 70 years since the end of World War II. Both the Soviet Union and Japan recorded economic performances equivalent to $2 / 3$ of the US's GDP at the time. And when each of those countries hit that $2 / 3$ ratio, America's policy posture towards them underwent a rapid change. In each case the instruments were different, as was the ferocity of implementation, but the results can be clearly seen for both countries: In 2018, neither comes close to their former economic strength. Japan's economy today is less than $1 / 4$ the size of the US's; Russia just $1 / 14$. Perhaps this is one of the reasons the phrase "Thucydides's Trap" quickly became known around the world ${ }^{3}$.

\section{Scientific progress: A massive but unpredictable factor}

One of the major components of secular changes is fast-paced technological progress. Our technological landscape is changing day by day, particularly with the

\footnotetext{
1 "Guided by the Socialist Diplomatic Thought with Chinese Characteristics in the New Era, Strive to Create a New Situation for the Diplomacy among Major Powers with Chinese characteristics", People's Daily, June 24, 2018.

${ }^{2}$ Zhang Yuyan, "Overcoming the Thucydides's Trap", World Economic and Politics, 2018, Issue 1, 2018, p. 1.

${ }^{3}$ Graham Allison, Destined for War: Can America and China Escape the Thucydides's Trap? Houghton Mifflin Harcourt, 2017.
} 
lightning pace of development in Internet and digital technologies. In turn, these new tools are driving chain reactions through production, distribution, allocation, and employment in every sector.

Automation and production lines in the manufacturing sector created huge numbers of new jobs (for engineers). But today's digital technologies and artificial intelligence are likely to destroy jobs without creating corresponding new positions. These new problems have motivated a series of important publications ${ }^{4}$ from economists like Daron Acemoglu, author of Why Nations Fail. McKinsey estimates that 800 million industrial workers will be replaced by robots by the year 2030. In theory, almost all jobs could one day be replaced as the price of artificial intelligence continues to fall. Where economic globalization and international foreign policy affect the relative statuses of different countries, the advancement of technology will drive change within each economy, exacerbating income inequality and holding down workers' wages.

In theory, new technologies should increase productivity. However, the reality has proved quite the opposite: In both developed economies like the US, the EU, and Japan and major emerging economies, efficiency is improving at a slower and slower rate since the $21^{\text {st }}$ century. The contrast with the massive investment in $R \& D$ is stark. This phenomenon has been christened the "productivity paradox" by economists, and it is indubitably creating a drag on the world economy.

New technologies are also starting to fundamentally alter the nature and form of warfare. An article ${ }^{5}$ in The Economists explains that digital military technology has led to the emergence of new, digital battle lines. Autonomous weapons are being developed and deployed in large numbers, which is changing our traditional understanding of what it means to be a soldier, and posing a new set of ethical questions: Can a smart weapon be a murderer? Military experts are also discussing "gray zone" conflict, which involves activity that is strategic and coercive, but does not escalate the situation and avoids a major response. In layman's terms, this is action where the target cannot precisely identify the aggressor, such as cyber-attacks and propaganda.

It is worth pondering that the accelerated networking of the world has greatly affected the power structure among countries. While not denying that the Internet is conducive to promote decentralization, it ironically awards network-dominated countries such as the United States enormous networking power in terms of the advantages of 'panopticons' and 'strokepoints' over other countries. Furthermore, these advantages are not only self-reinforcing, but also could be used as a weapon by networking hegemony ${ }^{6}$.

\section{Individual interests: Increased public awareness}

One of the obvious results of the spread of the Internet has been a precipitous drop in the cost of communications, a massive expansion in the content transmitted,

\footnotetext{
${ }^{4}$ Daron Acemoglu and Pascual Restrepo, "Modelling Automation", Feb. 2018, NBER Working Paper 24321; "Demographics and Automation”, March 2018, NBER Working Paper 24421; "The Wrong Kind of AI? Artificial Intelligence and the Future of Labor Demand", JEL, March 2019; "Automation and New Tasks: How Technology Displaces and Reinstates Labor", NBER Working Paper 25684.

${ }^{5}$ Salisbury Plain, "Autonomous Weapons and the New Laws of War", The Economists, Jan. $19^{\text {th }}, 2019$.

${ }^{6}$ Henry Farrell and Abraham L. Newman, "Weaponized Interdependence: How Global Economic Networks Shape State Coercion”, International Security, Vol. 44, No. 1, pp. 42-79, 2019.
} 
and a great boost in the speed of information transmission. This means much more access to information, new ideas, and communication. People today have a much clearer understanding of their own interests, and much more understanding of how to protect their rights. This widespread awareness of personal rights and interests is one of the major forces currently driving changes in society.

At the same time, populism and nationalism are rearing their heads on the political stage in certain countries. In Europe, the Italian far right is growing in strength. In Latin America, a "Trumpista" has taken the Brazilian presidency. It is a worrying trend for observers of world politics. Another consequence of digital technology has been the fragmentation of social cohesion. The information explosion that followed the arrival of the Internet means that information now flows to Internet users in a constant stream. As a result, they pay much less attention to their information, and a new "paradox of plenty" has developed ${ }^{7}$. Internet users prefer to see and hear information that suits their own preferences, so various media sources compete by honing their selection algorithms to deliver highly customized data; even fake news can look convincing when it comes from your own online contacts.

The "yellow vest" movement in France was the inevitable result of class groups who saw and read news only from within their own grouping, without any exchange or communication across class lines. When the Speaker of the US House of Representatives says, "I don't want to see [Trump] impeached. I want to see him in prison", the polarization of American society is plain for all to see.

Populist/nationalist parties and politicians taking the reins of power is an expression of the working classes, hit by the downside of globalization and connected by the Internet revolution. And their political successes will speed the spread of populism/nationalism around the world. The strength of this global movement will also determine whether the collapse of the current international order is followed quickly by the construction of a new system, or whether a long period of disorder intervenes.

Humanity has experienced two networking revolutions: The first was the spread of new knowledge through Europe following the invention of movable type by Gutenberg in the 1440s; the second was the interconnection of humanity in the 1970s after the invention of the computer and the Internet. In The Square and the Tower $^{8}$, Niall Ferguson concludes that the election of Donald Trump, the rise of ISIS, and the 2008 financial crisis, like the French and American revolutions and religious reform movements, all occurred in periods of expanding networks. The connected world is always in danger of descending into chaos of anarchy.

\section{Demographics: Crucial but complex}

Demographic change can be divided into changes in population age and changes in ethnic mix. The major developed nations are all experiencing some level of population aging. The effect is most pronounced in Japan and Europe. Population graying has also begun in certain developing nations, including China. An aging

\footnotetext{
${ }^{7}$ Joseph Nye, “American Soft Power in the Age of Trump", May 6, 2019, https://www.project-syndicate.org/commentary/american-soft-power-decline-under-trump-by-joseph-s-nye2019-05? barrier=accesspaylog.

${ }^{8}$ Niall Ferguson, The Square and Tower: Networks, Hierarchies and the Struggle for Global Power, Allen Lane, 2017.
} 
population brings numerous connected challenges, such as the sustainability of the welfare system, issues for macro policy, maintaining balance between savings and investments, and the political attitudes of older people.

We should also note that aging populations are not the only problem. In contrast, young populations in many emerging economies also present major challenges. In Africa, the Middle East, and India, we are seeing a population explosion. In some countries, $40 \%$ to $50 \%$ of the population are under the age of 25 . Such a young population inevitably results in serious unemployment among the youth. And a booming population can breed social instability, and take a heavy toll on resources.

Compared with the polarizing trend of demographics, shifts in the ethnic or racial mix can have a more direct effect on a country's social cohesion, political stability, and foreign policy. According to a survey report published in November 2017 by the Pew Research Center ${ }^{9}$, the number of Muslim citizens in the EU rose from 19.5 million in 2016 to 25.8 million in 2017, accounting for $4.9 \%$ of the EU's total population. Given a moderate rate of immigration growth, this ratio is predicted to increase to $11.2 \%$ in 2050; if a high growth rate is maintained, Muslim citizens will account for $19.7 \%$ of Germany's population in 2050 .

Today more than half of the babies born in the US do not have European ancestry. By 2024, half of the population under 20 will be non-white. Given these statistics, it's not difficult to understand the reason behind the "Muslim ban" that Trump tried to impose soon after he came to power.

The natural result of ethnically diverse society is the reinforcement of ethnic identity. Eric J. Hobsbawm, author of Nations and Nationalism Since $1780^{10}$, points out in the book that "one of the basic features of group or ethnic identity is to determine who the victims and the villains are. The villains are those to be held accountable for 'our' suffering. 'They' causes the anguish, disappointment, anxiety, and the sense of loss 'we' live with as a group. 'They' do not belong to the groups of 'us'; they are strangers, and thus are our enemies". Minority groups that are in constant conflict tend to reject good will and tolerance of other groups. It may even be political wisdom to see to it that some enemies are identified in order to ensure the group's effectiveness, unify its members, and ensure these members remain conscious of their unity. Extreme situations in which we see the rise of ethnic identity and conflict within one nation, or between nations, is the focus of The Clash of Civilizations and the Remaking of World Order ${ }^{11}$, by renowned American political scientist, Samuel Huntington.

\section{Post-WWII dollar economy: Nearing a crossroads}

A new round of diversification - or de-dollarization - in the world economy has gained momentum and attracted wide attention in recent years. At market exchange rates, the US represents $22 \%$ of the world economy; measured by purchasing power parity, it is $15 \%$. However, the US dollar accounts for half or more of crossborder invoicing, settlements, reserves, liquidity and funding. In an article titled

\footnotetext{
${ }^{9}$ https://www.pewresearch.org/fact-tank/2017/11/29/5-facts-about-the-muslim-populationin-europe/

${ }^{10}$ E. J. Hobsbawm, Nations and Nationalism Since 1780: Programme, Myth, Reality (Canto Classics), $2^{\text {nd }}$ Edition, Cambridge University Press, 2012, Chapter 6.

${ }^{11}$ Samuel Huntington, The Clash of Civilizations and the Remaking of World Order, Xinhua Publishing House, 2010.
} 
Trump's Policies Will Displace the Dollar ${ }^{12}$, Professor Jeffrey Sachs notes that the US reaps many benefits from the dollar's predominant role as a reserve currency. It can collect exorbitant seigniorage on dollar reserves, avoid exchange rate risk, easily sell banking services to other countries around the world, minimize the cost of financial transactions, affect the pricing of commodities, and exercise significant influence over other countries' policies, particularly those that use the dollar extensively.

The creation of the euro, and the increased international use of the renminbi following the 2008 financial crisis both increased diversity in the international monetary system. Now the determination of many major economies to end their reliance on the dollar has been reinforced by Trump's trade wars, America's ballooning budget deficits, and the use of the dollar-based SWIFT settlement system to monitor global financial activities and apply economic sanctions.

In 2018, Turkey began to divest its US dollar assets. Iran has announced that it will price its oil in euros rather than dollars. Russia sensed that the dollar was now a risky currency for conducting international transactions, and has started to increase the use of the euro, ruble, and even the renminbi instead. Shanghai International Energy Exchange has launched a renminbi-denominated crude future product, and trading volumes are steadily growing. Meanwhile, China's Cross-Border Interbank Payment System (CIPS), an international settlement system using the renminbi, has now scaled up beyond the original limited rollout. Reforms to the international monetary system are a perennial topic at BRICS summits, and the world has seen the establishment of the BRICS Contingent Reserve Arrangement (CRA) and the New Development Bank. The group may well launch its own cryptocurrency. The Instrument in Support of Trade Exchanges (INSTEX) is a highly significant new development. This instrument was set up by the UK, France, and Germany to enable trade with Iran, and uses the euro in order to circumvent US sanctions.

In an article titled Trump's Economic War of Choice ${ }^{13}$, published at the end of 2018, Jim O'Neill, a former chairman of Goldman Sachs Asset Management and a former UK Treasury Minister, wrote, "At some point, the dollar's status as a global means of payment and reserve currency could be challenged". The international monetary system is a large and complex force. Its actions impact directly on the international status of the dollar, one of the pillars of US hegemony. But it also has a role to play in global economic stability and long-term growth, and it is directly implicated in the fate of digital currencies, such as Libra, issued by technology giants.

\section{Multilateral system: Time for dissolution and reconstruction}

One of the symptoms of secular change will be the dissolution and reformation of the existing multilateral order. The Trump administration has already withdrawn the US from the Paris Agreement, the Trans-Pacific Partnership (TPP), and the UN Human Rights Council; it terminated the Iran nuclear accord and the IntermediateRange Nuclear Forces (INF) Treaty; the US administration has considered leaving the World Trade Organization, and has sharply attacked NATO and even the UN. The US appears to be voluntarily abandoning the postwar international order that it so painstakingly built.

\footnotetext{
12 Jeffrey D. Sachs, "Trump's Policies will displace the Dollar", https://www.project-syndicate.org/commentary/trump-policies-undermining-the-dollar-by-jeffrey-d-sachs-2018-9-3.

${ }^{13}$ Jim O’Neill, “Trump's Economic War of Choice”, Lianhe Zaobao, December 15, 2018.
} 
There are some who locate the causes of the collapse of the current order in the failure of the US's democratic system and its consequent decline, the swift rise of China, and the revival of Russia. However, from the perspective of liberal theories - still the dominant school in international relations - the formation of international alliances is a crucial pillar in the story of America's success. Trump's unilateralism ${ }^{14}$ and protectionism will destroy it.

From an economic perspective, trade wars have no winners (at least in the short to medium term), only two losers. Because of this, many have said that Trump's behavior is irrational, but his policies do have their own internal logic. Over the last 40 years, American GDP per capita has risen by more than US\$50,000. One of the primary drivers of this growth has been the enthusiastic engagement of China with the globalization process dominated by developed nations. Supporting globalization is the international system carefully planned and constructed by the US since World War II. The underlying cause for America's abandonment of an international system that has brought it massive benefits is the rise of a new power: China.

China is threatening America's position of dominance within the global order. Size is a unique and vital factor in the rough-and-tumble of international relations. Major powers seek not just an economic edge over other countries, but also political superiority. The fundamental difference between politics and economics is that in economic terms, you can choose to align, and seek shared benefits for all; in politics you always seek to put the greatest possible distance between yourself and your competitors.

The worsening global situation has highlighted a global governance deficit, which shows an objective and pressing need for major improvements in the international order.

According to the IUCN Red List $2018^{15}$ update, of the 100,000 species assessed, more than 28,000 species are threatened with extinction. That is $28 \%$ of all assessed species. Since 1970, the number of vertebrates on the planet has decreased by $60 \%$, and only $30 \%$ of the original bluefin tuna population still exists due to overfishing in the Pacific Ocean. Studies have also shown that the current species extinction rate is 100 to 10,000 times the normal rate.

Given our unique historical predicament, if humanity refuses to take collective action and stop the mass extinction, then the very existence of humanity will be threatened, because of the collapse of the food chain.

I fear that this is the reason why the multilateral order has started to disintegrate, and new ideas for global governance are continually emerging. The Belt and Road Initiative launched by China, and its gradual institutionalization, can be seen as a representative example of international order-building.

\section{The US: A superpower in decline}

Charles Calomiris ${ }^{16}$ writes that the 2008 financial crisis in some senses reveals how ossified US systems have become, and the severity of the damage that this inflexibility can cause. In the US, financial crises and credit scarcity are not distributed purely randomly. They are the result of political competition and negotiation.

\footnotetext{
${ }^{14}$ Fareed Zakaria, "The Self-Destruction of American Power: Washington Squandered the Unipolar Moment”, Foreign Affairs, July/August, Vol. 98, No. 4, 2019.

${ }^{15}$ The IUCN Red List of Threatened Species 2018: https://www.iucnredlist.org

${ }^{16}$ Charles Calomiris, Fragile by Design, Princeton University Press, 2014.
} 
The banking system is the outcome of political horse-trading. The interests of various stakeholders in the political process determine how banking policy is shaped, including all aspects from the issuing of banking licenses to the parameters of branches, the allocation of credit, regulatory arrangements and banking relationships.

In America, Compromised ${ }^{17}$, Lawrence Lessig is concerned not with assigning blame to the villains, but with how American institutions foster corruption and ultimately lead the country to harmful outcomes. He sees institutions in the financial, legal, media, healthcare, and research sectors as all being corroded by the wrong standards and incentives. They in turn corrode other industries. The problem is not always the selfish behavior of specific actors.

Steven Brill argues that, "The First Amendment became a tool for the wealthy to put a thumb on the scales of democracy. America's rightly celebrated dedication to due process was used as an instrument to block government from enforcing jobsafety rules, holding corporate criminals accountable and otherwise protecting the unprotected. Election reforms meant to enhance democracy wound up undercutting democracy. Ingenious financial and legal engineering turned our economy from an engine of long-term growth and shared prosperity into a casino with only a few big winners... lobbyists were able to get riders or exemptions worth billions inserted into [almost all] legislation... the country [has been split] into two classes: the protected and the unprotected. The protected overmatched, overran and paralyzed the government. The unprotected were left even further behind... voter turnout... and respect for basic institutions, especially the government - are far below what they were... For adults in their $30 \mathrm{~s}$, the chance of earning more than their parents dropped to $50 \%$ from $90 \% 40$ years ago" 18 .

Nepotism is also much more widespread in the US than is commonly imagined. An article in The Economist ${ }^{19}$ reported that the son of a state governor had 600 times as much chance as a male baby boomer of becoming a governor; the son of a senator was 8,500 times more likely to become a senator than an ordinary person.

Many signs show that the US is on the way to becoming a high welfare state. A large majority of Americans support increased welfare spending. If the health insurance that is not currently paid for by the government were added on, then total US government expenditures would amount to $48 \%$ of the country's GDP - virtually the same level as Sweden, the poster child of European welfare states. Many worry that this could put a permanent squeeze on America's capacity for growth. Despite the recent run of 122 straight months of positive GDP growth - breaking the previous record set between 1991 and 2001 - in all that time the country has only expanded by $25 \%$. This is far lower than the $43 \%$ total growth achieved over the previous long run.

\section{Increasing tension: Confinement and countermeasures}

"Power politics" traditionally refers to the jockeying of major powers for advantage, sometimes including ruthless subjugation of the other country even at one's own expense. Many of the reasons for the secular changes occurring today can be boiled down to one: China is swiftly developing its own high-tech industries. But

\footnotetext{
${ }^{17}$ Lawrence Lessig, America, compromised, University of Chicago Press, 2018.

${ }^{18}$ Steven Brill, "How Baby boomers Broke America", The Times, May 28, 2018.

${ }^{19}$ Cover Story: "Dynasties: The Power of Families", The Economist, April 18, 2015.
} 
at the very least, China-US relations have not yet begun a new cold war. During the cold war, the US's posture towards the Soviet Union was one of isolation and containment. To the greatest extent possible, it avoided any trade or private engagement with the Soviet Union and its allies. Ultimately, this forced the Soviet Union into a spiral of inefficiency so that it stifled itself.

During the cold war and for the following decade or more, America's policy toward China was of engagement. At its core was the aim of drawing China into the America-dominated international system, to induce it to take on certain obligations, and thus to influence China itself. Though there are now voices in America calling for a disengagement with China, and ultimately a new policy of containment, the US would find it almost impossible to truly isolate China. And in fact, it has no need to do so. It would be impossible because isolating China would require coordinated action by all of the world's major economies and a large number of the developing ones. And it is unnecessary because the threat posed by China toward the US and other developed nations comes from the possibility of overtaking them in high-tech sectors, not from low-end competition.

The vital core of US policy toward China is to continue to enjoy the benefits of having China fill out the low end of the value chain in global manufacturing, while preventing China from catching up in high-tech sectors, particularly in digital technologies. This fundamental policy towards China can be described in a single, simple word: confinement ${ }^{20}$.

There are two goals to the confinement policy: One is to use international rules to limit China's ability to act in high-tech sectors; the other is to lock China into global supply chains in a low-value position, and to maintain or even widen the technological gap between China and the US. The US's frequent application of its own internal law to its trade partners is motivated mainly by the fact that the current multilateral system is not constraining China as America would like it to. The most obvious example is the 301 Report $^{21}$ publish by the US Trade Representative in March 2018. This report focused entirely on technology-related questions, including alleged issues of technology theft, forced technology transfer, and intellectual property protection. The same objective motivated the joint statement issued by the US, Europe, and Japan calling for a reform of WTO rules, and demands for transparency from the Chinese government on subsidies.

As Bloomberg News reported on May 26, 2019, under the headline Tech Cold War Will Force World to Choose $e^{22}$, "the digital Iron Curtain will force political leaders to decide whether they're Team China or Team America". In a word, the tussle between the US and China, as they attempt to confine and break each other's bonds, has become a modern form of Thucydides' trap, and the rest of the world is already feeling the impact.

\section{Constants hold true amid secular change}

Change always contains constants within it; constancy holds the seeds of change. The explosion of the very first atomic bomb instantly changed the course

\footnotetext{
${ }^{20}$ Zhang Yuyan and Feng Weijiang, "From Contact to Confinement: Four Prospects of the U.S. Strategic Intention towards China and the Bilateral Game", Tsinghua Financial Review, No. 7, 2018

${ }^{21}$ Refer to: https://ustr.gov/issue-areas/enforcement/section-301-investigations/tariff-actions

${ }^{22}$ Tim Culpan, "The Tech Cold War has Begun", https://www.bloomberg.com/opinion/ articles/2019-05-20/huawei-supply-freeze-points-to-u-s-china-tech-cold-war
} 
of human history. In Why the West Rules - For Now ${ }^{23}$, Ian Morris observes that neither great individuals nor bungling idiots can change the course of history. At most they can accelerate or slow the turning of its wheels. But in the period after 1945, political leaders were able to change history. In the past, the consequences of any human error would be the decline or collapse of some community. Now we had the capacity to make errors that would bring about the end of our species.

Since that moment, we have remained firmly in the nuclear age. The Stockholm International Peace Research Institute (SIPRI) estimates that there are now over 15,850 nuclear warheads ${ }^{24}$ in the world. The US and Russia have about 6,550 and 6,850 , respectively. This is sufficient to destroy all of humanity ten times over, and means that humankind continues to live in the shadow of death. And the continued existence of nuclear weapons places a hard upper limit on any conflict between the US, Russia, and China, because all-out war between nuclear powers would undoubtedly result in the destruction of humanity.

Another constant that has remained unchanged is that interdependence between nations is at an all-time historical high. This interdependence is seen in the high levels of national specialization and the deep trade links spanning the globe. In an article titled Five Myths about Globalization ${ }^{25}$, Steven Altman offers evidence globalization - measured based on flows of trade, capital, information and people rose to a record high in 2017. The world is bound closely together in global chains of supply and value. While it is still true that the "systems integrators" 26 who occupy the very highest rungs of the value chain are still mainly to be found in North America, Europe, and Japan, the cost of disengagement between the major developed and developing nations has risen to a level that the world cannot afford. The benefits of trade to every nation have helped dampen the inevitable public and political backlash within each country, and are canceling out any anti-globalization effect. Overall, there has been no reversal of globalization; at most a temporary hiccup in its progress. Economic globalization is a major historical process, and it does not always proceed forward serenely and smoothly. Its path is inevitably winding and bumpy. The Trump administration, with its unilateralism, protectionism, and hectoring tone, is just one manifestation of globalization's twists and turns.

\section{Looking back a century hence}

In a hundred years' time, when historians look back on this particular period of the human experience, they are likely to see this moment of secular change as one step in the rise of the East, particularly China; and one moment in the West's ongoing response led by the US. Two major powers like China and the US, one swiftly rising, one still holding on to a slightly tired superpower status... One grasping for global status to match its strength, the other reluctant to share power with any other state... One driven by the deep political traditions of Asia, the other a product of Western enlightenment and Christian inspiration... It is only natural and normal that two powers such as these should bump heads, rub up against each other, even find themselves in collision and conflict. But from another perspective, we can clearly see that many of the global issues that humanity faces require the world's

\footnotetext{
${ }^{23}$ Ian Morris, Why the West Rules - For Now, CITIC Press Group, 2011.

${ }^{24}$ SIPRI Yearbook 2018, https://www.sipri.org/yearbook/2018. Besides the U.S. and Russia, France has listed No. 3 with 300.

${ }^{25}$ Steven Altman, "Five Myths about Globalization”, Washington Post, Feb. 12, 2019.

${ }^{26}$ Peter Nolan, Is China Buying the World?, Polity, 2013.
} 
two biggest powers to work together. These two largest stakeholders in the common affairs of humanity must jointly take responsibility and meet our challenges. And the necessary first step on this path is for both China and the US to apply their wisdom and their courage, and to resolve the misunderstandings, tensions, and conflicts between our great nations.

\section{REFERENCES}

Acemoglu D. and Restrepo P., "Modelling Automation", NBER Working Paper 24321, Feb. 2018; "Demographic sand Automation", NBER Working Paper 24421, March 2018; "The Wrong Kind of AI? Artificial Intelligence and the Future of Labor Demand", JEL, March 2019; "Automation and New Tasks: How Technology Displaces and Reinstates Labor", NBER Working Paper 25684, 2019.

Altman S. (2019), "Five Myths about Globalization", Washington Post, February 12 .

Brill S. (2018), "How Baby Boomers Broke America”, The Times, May 28.

Culpan T., "The Teck Cold War Begun", available at: https://www.bloomberg. com/opinion/articles/2019-05-20/huawei-supply-freeze-points-to-u-s-china-techcold-war (accessed 2 June 2019).

"Dynasties: The Power of Families", The Economist, April 18, 2015.

Farrell H. and Newman A. L. (2019), "Weaponized Interdependence: How Global Economic Networks Shape State Coercion”, International Security, Vol. 44, No. 1, pp. 42-79.

Ferguson N. (2017), The Square and Tower: Networks, Hierarchies and the Struggle for Global Power, Allen Lane, London.

Lessig L. (2018), America, Compromised, University of Chicago Press, Chicago, IL.

Nye J. (2019), "American Soft Power in the Age of Trump", May 6, available at: www.project-syndicate.org/commentary/american-soft-power-decline-undertrump-by-joseph-s-nye-2019-05-6/ (accessed 2 June 2019).

Plain S. (2019), "Autonomous Weapons and the New Laws of War", The Economist, January 19.

Sachs J. D., "Trump's Policies Will Displace the Dollar", available at: www. project-syndicate.org/commentary/trump-policies-undermining-the-dollar-by-jeffrey-d-sachs-2018-09 (accessed 2 June 2019).

"Shades of Grey, Neither War Nor Peace", The Economist, January 25, 2018.

Zakaria F. (2019), "The Self-Destruction of American Power: Washington Squandered the Unipolar Moment", Foreign Affairs, July/August, Vol. 98, No. 4.

\section{РОЗУМІННЯ “ВЕЛИКИХ ТРАНСФОРМАЦІЙ РАЗ НА СТОЛІТТЯ” \\ Чжан Юйянь}

Нині світ зазнає небачених змін за століття, які матимуть більший вплив на майбутнє людства, ніж усі трансформації XX століття. Цей період $є$ найкращим у розвитку Китаю в сучасній історії. Стаття актуальна, адже можна дізнатись про те, як і чому змінюється світ, в якому напрямку. У першу чергу йдеться про фундаментальні зрушення у співвідношенні сил між великими державами, а саме у відносинах між Китаєм та США. Крім того, із найважливіших змін світу $є$ технологічний прогрес, який викликає ланцюгову реакцію масових, але іноді непередбачуваних змін у виробництві, розподілі, обміні та зайнятості у кожному секторі. Як наслідок маємо ще один фактор змін - поширення інтернету, що призвело до інформаційного вибуху, падіння вартості комунікацій. Також розглянуто демографічні зміни, які викликають 
нові проблеми на шляху до економічної, соціальної, політичної стабільності та зростання.

Привертає увагу і зміна позицій США за рахунок дедоларизації. США отримує багато переваг від статусу долара як резервної валюти, проте посилюється різноманітність у міжнародній системі, зокрема цифрових валют, залежність інших країн від долара зменшується. Відповідно до послаблення країни, яка побудувала процес глобалізації, та посилення іншої країни - Китаю, відбуваються зміни у міжнародній системі, про що детально йдеться у статті. Америка та Китай не розв'язали холодну війну, проте потрапили у пастку Фукідіда, і світ вже відчуває вплив.

Усі зміни мають свої константи, у даному випадку: ми міцно лишились у ядерній епосі, і взаємозалежність між націями перебуває на найвищому історичному рівні. Озираючись через сто років на зміни в цей період, історики, ймовірно, зможуть розглядати цей момент як етап підйому Сходу, особливо Китаю.

Ключові слова: Китай, США, трансформації ХХ століття, технологічний прогрес, історичні зміни, інформаційний вибух, процес глобалізації

\section{ПОНИМАНИЕ "ВЕЛИКИХ ТРАНСФОРМАЦИЙ РАЗ В СТОЛЕТИЕ" \\ Чжан Юйянь}

Сейчас мир испытывает невиданные изменения за столетия, которые будут иметь большее влияние на будущее человечества, чем все трансформации XX века. Этот период является лучшим в развитии Китая в современной истории. Статья актуальна и позволяет узнать о том, как и почему меняется мир, в каком направлении. В первую очередь речь идет о фундаментальных сдвигах в соотношении сил между лидирующими странами, а именно в отношениях между Китаем и США. Кроме того, важнейшим изменением в мире является технологический прогресс, который вызывает цепную реакцию массовых и иногда непредсказуемых изменений в производстве, распределении, обмене и занятости в каждом секторе. В результате имеем еще один фактор изменений - распространение интернета, что привело к информационному взрыву, падению стоимости коммуникаций. Также в статье рассмотрены демографические изменения, которые вызывают новые проблемы на пути к экономической, социальной, политической стабильности и росту.

Привлекает внимание также изменение позиций США за счет дедолларизации. США получает много преимуществ от статуса доллара как резервной валюты, однако усиливается разнообразие в международной системе, в частности цифровых валют, в результате чего зависимость других стран от доллара уменьшается. В соответствии с ослаблением страны, которая построила процесс глобализации, и усилением другой страны - Китая, происходят изменения в международной системе, о чем детально говорится в статье. Америка и Китай не начали холодную войну, однако попали в ловушку Фукидида, в связи с чем мир уже испытывает влияние.

Все изменения имеют свои константы, в данном случае: мы крепко остались в ядерной эпохе, и взаимозависимость между нациями находится на высоком историческом уровне. Оглядываясь через сто лет на изменения за этот период, историки, вероятно, будут рассматривать этот момент как этап подъема Востока, особенно Китая.

Ключевые слова: Китай, США, трансформации XX века, технологический прогресс, исторические изменения, информационный взрыв, процесс глобализации 